\title{
The occurrence of Pomphorhynchus laevis (Acanthocephala) in cage- reared rainbow trout (Oncorhynchus mykiss) from Işıklı Spring, Çivril, Turkey
}

\section{Işıklı KaynağIı, Çivril'de ağ kafeslerde yetiştirilen gökkuşağı alabalığı (Oncorhynchus mykiss)'nda Pomphorhynchus laevis (Acanthocephala) varlığı}

\section{Dilara Sözeren Çevrimel ${ }^{1}$ - Erhan Soylu ${ }^{2 *}$}

${ }^{1}$ Fisheries Department, Institute for Graduate Studies in Pure and Applied Sciences, Marmara University, Göztepe, TR-34722 Kadıköy, Istanbul, Turkey ${ }^{2}$ Fisheries Department, Vocational School of Technical Sciences, Marmara University, Göztepe, TR-34722 Kadıköy, Istanbul, Turkey

Corresponding author: esoylu@marmara.edu.tr

\section{How to cite this paper:}

Sözeren Çevrimel, D. \& Soylu, E. (2017). The occurrence of Pomphorhynchus laevis (Acanthocephala) in cage-reared rainbow trout Oncorhynchus mykiss from Işıklı Spring, Çivril, Turkey. Ege Journal of Fisheries and Aquatic Sciences, 34(3): 255-260. doi:10.12714/egejfas.2017.34.3.02

\begin{abstract}
Occurrence of Pomphorhynchus laevis (Müller, 1776) in cage-reared rainbow trout Oncorhynchus mykiss (Walbaum, 1792) and the effects of parasitism on the fish condition were studied between July and November 2014 in Işıkı Spring. A total of 221 O. mykiss specimens were examined. In addition to $P$. laevis, three other parasite species; Trichodina sp., Ichthyophthirius multifiliis Fouquet, 1876 and Diplostomum sp. were also recorded. P. laevis was numerically the predominant species with the highest prevalence (77.8\%), mean intensity (6.74), and mean abundance (5.24). In total $1160 P$. laevis specimens were collected. The mean abundance of $P$. laevis increased over a period of months from 2.5 individual parasites per fish in July to 7.1 in November. The mean intensity of $P$. laevis increased with increasing fish host length from 1.5 in the 5.0-6.9 cm length class to 18.4 in the $25.0-26.9 \mathrm{~cm}$ length class. Although there was no statistically significant bias in the spatial distribution of $P$. laevis within the gut $(p>0.05)$, the parasite tended to prefer the pyloric caeca $(47.9 \%)$. The larval stage (cystacanth) of the acanthocephalan parasite were obtained from the haemocoel of Gammarus obnixus Karaman and Pinkster, 1977. The value of Fulton's condition factor (K) ranged from 0.84 to 1.66 .
\end{abstract}

Keywords: Oncorhynchus mykiss, cage-reared, parasites, Pomphorhynchus laevis

Öz: Ağ kafeslerde yetiştirilen gökkuşağı alabalığı Oncorhynchus mykiss (Walbaum, 1792)'nda Pomphorhynchus laevis (Müller, 1776) varlığı ve balık kondüsyonu üzerindeki paraziter etki Işıkı Kaynağı'nda Temmuz ve Kasım 2014 süresinde çalışıldı. Toplam 221 O. mykiss örneği incelendi. P. laevis den başka üç diğer parazit türü; Trichodina sp., Ichthyophthirius multifiliis Fouquet, 1876 ve Diplostomum sp. da kaydedildi. $P$. laevis yaygınlık (\%77.8), ortalama yoğunluk (6.74) ve ortalama çokluk (5.24) ile sayısal olarak baskın parazitti. Toplamda $1160 P$. laevis örneği toplandı. $P$. laevis ortalama çokluğu, aylık devrelerde Temmuz'da her balıkta 2.5 parazit bireyinden Kasım'da 7.1'e yükseldi. $P$. laevis ortalama yoğunluğu, artan balık uzunluğu ile $5.0-6.9 \mathrm{~cm}$ lik boy sınıfında 1.5 'den $25.0-26.9 \mathrm{~cm}$ lik boy sınıfinda 18.4'e yükseldi. Sindirim kanalında $P$. laevis'in uzamsal dağlımında istatistik olarak belirgin bir eğilim olmamasına karşın $(p>0.05)$ parazit tercihi pilorik çekaya (\%47.9) yönelik olmuștur. Acanthocephalan parazitin larval dönemi (cystacanth), Gammarus obnixus Karaman and Pinkster, 1977' un vücut boșluğunda bulunmuştur. Fulton Kondisyon Faktörü değerleri (K), 0.84 ile 1.66 arasına yayılmıştır.

Anahtar kelimeler: Oncorhynchus mykiss, kafes yetiştiriciliği, parazit, Pomphorhynchus laevis

\section{INTRODUCTION}

Acanthocephalans of the genus Pomphorhynchus Monticelli, 1905 (Echinorhynchida: Pomphorhynchidae) are intestinal, non-specific parasites of a number of marine and freshwater fishes being their definitive or paratenic hosts ( Kirin et al., 2014; Taraschewski, 2000). Like all fish acanthocephalans, they require trophic transmission to complete their life cycle using water amphipods as their intermediate hosts (Dezfuli et al., 2008). The arthropod intermediate host becomes infected by eating the acanthocephalan egg, and the acanthor larva is free into the host's digestive tract. The larva bores through the gut wall into the body cavity where it develops from acanthella to cystacanth, which can infect the vertebrate host (Dezfuli et al., 2011). The proboscis and bulb of Pomphorhynchus acanthocephalans deeply penetrate the entire gut wall of the fish host and lead to extensive damage to the digestive tract 
(Dezfuli et al., 2002). The density of the parasite burden and the depth of penetration of the acanthocephalans are two main factors for their pathogenicity (Bullock, 1963). In amphipods, $P$. laevis has been recorded as the most abundant larval helminth (Dezfuli et al., 1999).

Recently, two genetically distinct but morphologically close species of Pomphorhynchus; $P$. laevis Müller, 1776 and $P$. tereticollis (Rodolphi, 1809), have been detected throughout Europe (Perrot-Minnot, 2004; Bombarova et al., 2007; Špakulová et al., 2011). P. tereticollis was treated as a synonym of $P$. laevis for a long time, but the species has been resurrected and re-described by Špakulová et al., (2011) on the basis of some morphological and molecular features. In Turkey, some authors have recorded $P$. laevis in freshwater fishes and also amphibian hosts (Yıldız and Çavuşoğlu 2003). On the other hand, Smales et al., (2012) recorded P. tereticollis in Great Beyşehir Spined Loach Cobitis bilseli Battalgil, 1942 (Cobitidae) from Lake Beysehir, Turkey. Düşen and Oğuz (2008), recovered $P$. laevis from Marsh frog (Rana ridibunda) in Lake Işıklı. Heckmann et al., (2010) identified $P$. spindletruncatus in the intestine of the marsh frog Pelophylax ridibundus (Pallas, 1771) from Işıkı Lake. In the present study, we observed the frequent occurrence of Pomphorhynchus infection in cage-reared rainbow trout Oncorhynchus mykiss. Although the structure of the proboscis hooks in the presently reported species reveals close similarity to $P$. tereticollis, the first molecular analysis suggests $P$. laevis (Špakulová and Perrot-Minnot, personal communication)

\section{MATERIALS AND METHODS}

The fish specimens were sampled between July and November 2014 from net-cages close to Işıklı Spring (38 $18^{\prime}$ $\left.55.67^{\prime \prime} \mathrm{N}, 29^{\circ} 51^{\prime} 38.29^{\prime \prime} \mathrm{E}\right)$. In total, 221 Oncorhynchus mykiss specimens of mean $( \pm \mathrm{SD})$ total length $14.79 \pm 4.65 \mathrm{~cm}$ (ranging from 5.1 to $27.8 \mathrm{~cm}$ ) and mean ( \pm SD) weight $53.90 \pm$ $54.87 \mathrm{~g}$ (ranging from 1.9 to $287.1 \mathrm{~g}$ ) were examined. The fish were transported to the laboratory alive, where they were weighed and measured. Fish were anaesthetised using MS 222 and their spinal cords cut with dissecting scissors. During the dissection, the skin, vitreous humour, eye lens, mouth and nasal cavities, gills, gonads, spleen, digestive tract, kidneys, swim bladder, peritoneum and muscles were examined for parasites. The digestive tracts were removed, opened longitudinally and examined for parasites, which were recorded by number and location. The condition factor of the fish was calculated using Fulton's formula: $\mathrm{K}=\mathrm{W} \times 100 / \mathrm{L}^{3}$, where $\mathrm{W}=$ fish weight in grams, $L=$ total length of fish in centimetres. Differences in the spatial distribution of $P$. laevis in the digestive tract and the differences in the number of $P$. laevis and the condition factor between the size classes were analysed using the Kruskal-Wallis $\mathrm{H}$ test. One-way analysis of variance (ANOVA) was used to determine differences in condition factors between the fish size classes. A total of 617 specimens of Gammarus obnixus were collected, using a hand net $(2 \mathrm{~mm}$ mesh) sweeping over submerged plants. Amphipod specimens fixed with $4 \%$ formalin and cleared in lactic acid-glycerinewater. They were measured and sexed and infected individuals were separated for the counting of cystacanths. Identification of acanthocephalan specimens was performed as described by Špakulová et al., (2011) using unfixed fresh material and then by mitochondrial and nuclear sequencing. Identification of the other parasites were made according to Niewiadomska, (2003) and Bykhovskaya-Pavlovskaya et al., (1962). Species names of Gammarus obnixus and G. balcanicus Schaferna, 1922 were based on (Aygen and Balık, 2005). The prevalence, mean intensity and abundance were determined as defined by Bush et al. (1997).

\section{RESULTS}

During the study period, a total of 2210 . mykiss specimens were examined. The water temperature ranged from $10.5^{\circ}$ $19.3^{\circ} \mathrm{C}$, and dissolved oxygen concentrations ranged $5.7 \mathrm{mg} / \mathrm{l}$ in mid summer and increase to $13.8 \mathrm{mg} / \mathrm{l}$ in late fall at the cage area. Four parasite species were identified on/in the fish host: Trichodina sp., Ichthyophthirius multifiliis, Diplostomum sp. and Pomphorhynchus laevis (Figs 2, 3).

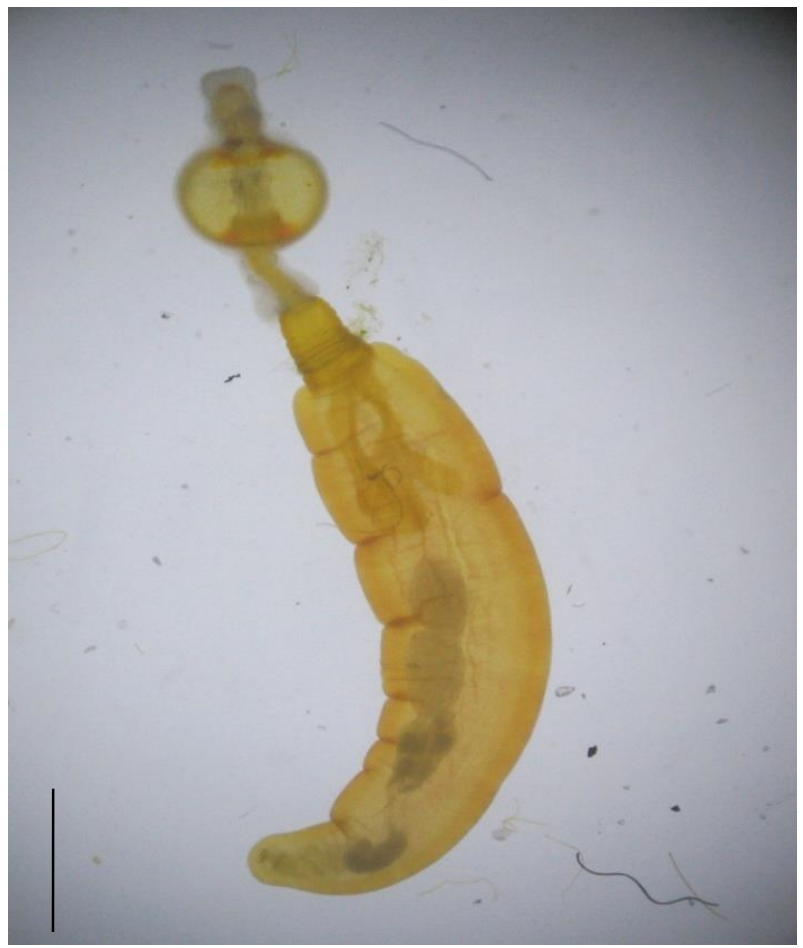

Figure 2. Male of Pomphorhynchus laevis in Oncorhynchus mykiss from Işıkı Spring (bar $=2 \mathrm{~mm})$

Identification of acanthocephalan specimens was performed on living or fresh worms and the following morphological features found: (first four to five hooks longest, fifth or sixth hooks stoutest and significantly shorter (Fig 4), hooks on the posterior half of proboscis have proximal projections on the base (Fig 5), last hook row stands at the posterior-most end of the proboscis (Fig 6) reveals close similarity to $P$. tereticollis. 


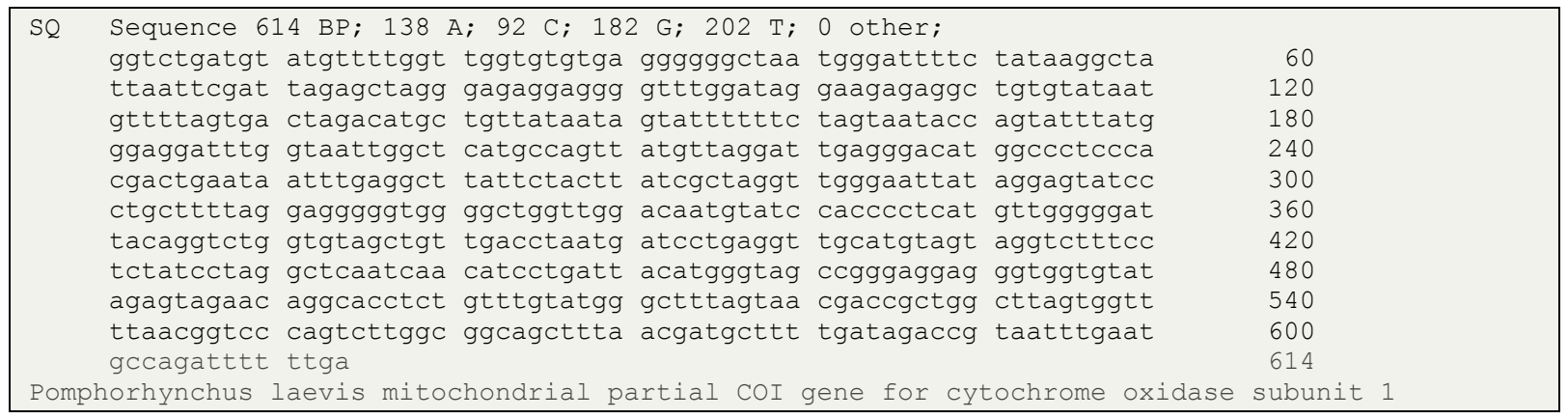

Figure 1. Sequences of mitochondrial partial $\mathrm{COI}$ gene for cytochrome oxidase subunite 1 of the acanthocephalan specimen from Işıklı Spring

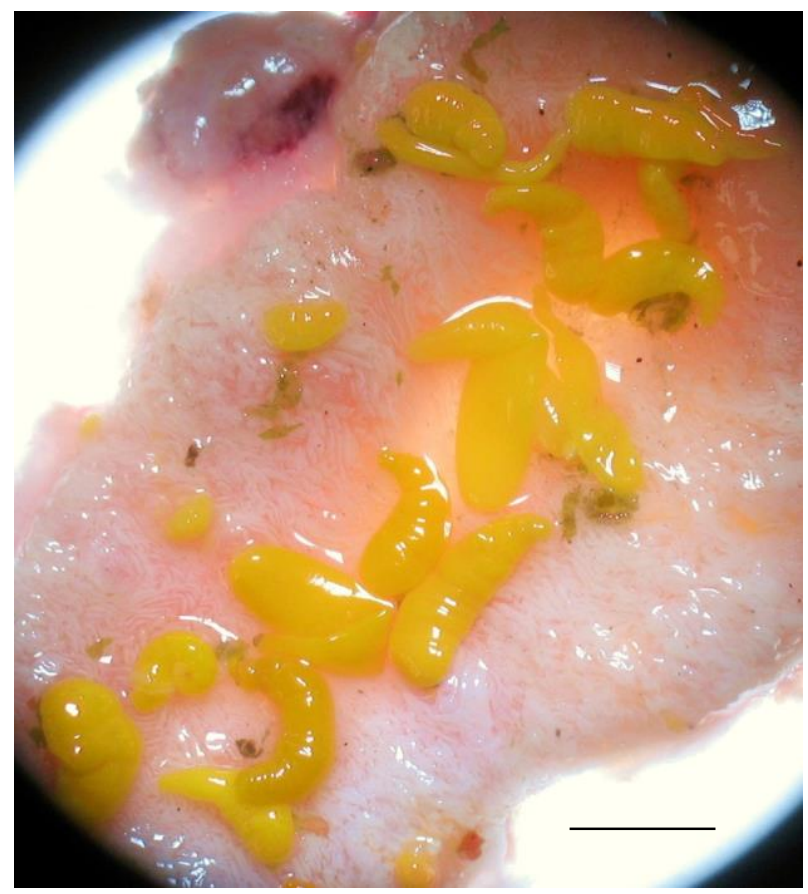

Figure 3. Pomphorhynchus laevis in the intestine of Oncorhynchus mykiss from Işıklı Spring (bar $=5 \mathrm{~mm}$ )

But the first molecular analysis of mitochondrial partial $\mathrm{COI}$ gene for cytochrome oxidase subunite 1 determined the parasite specimens as Pomphorhynchus laevis (Figure 1).

The parasite infracommunity of the Oncorhynchus mykiss was strongly dominated by $P$. laevis and 172 fishes were found to be infected by a total of $1160 P$. laevis individuals. The overall prevalence, mean intensity and mean abundance were determined as $77.8 \%, 6.74$ and 5.24 respectively. The other three parasite species: I. multifilis (prevalence 5.88\%), Diplostomum sp. (0.45\%) and Trichodina sp. (1.80\%) were very scarce. The mean intensity of $P$. laevis in the fish host increased from 2.5 in July, 2.7 in August, 5.2 in September and 4.4 in October to 7.1 in November and the infection intensity ranged from 1 to 63 worms per host. The mean intensity of $P$. laevis increased with increasing host total length, from 1.5 in the $5.0-6.9 \mathrm{~cm}$ length class to 18.4 in the $25.0-26.9 \mathrm{~cm}$ length

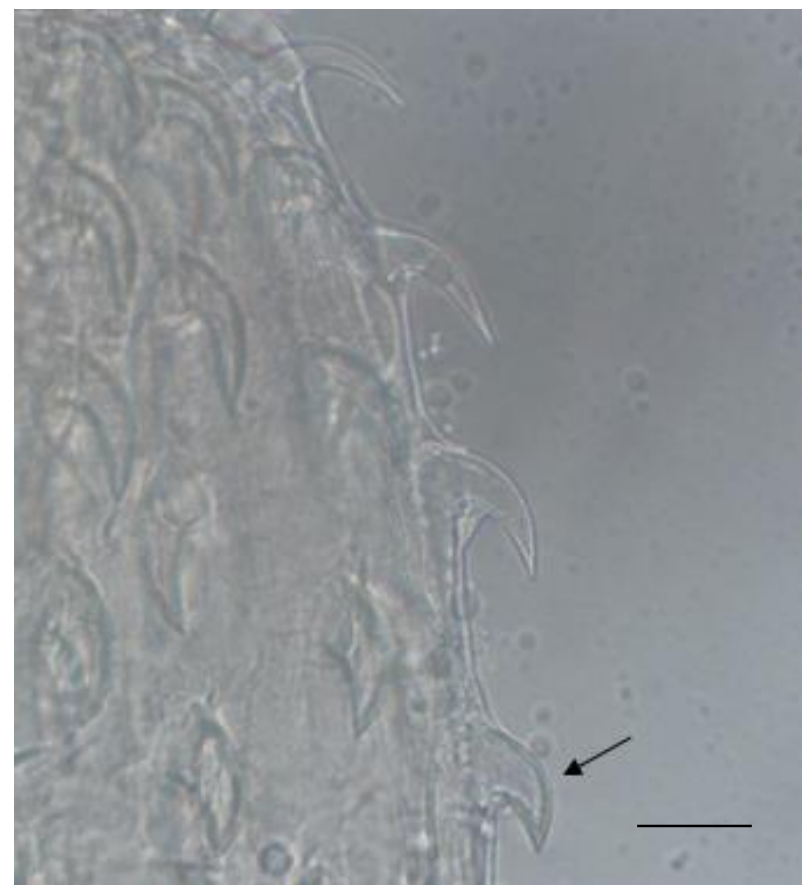

Figure 4. The first four to five hooks longest, fifth or sixth hooks (arrow) stoutest on the proboscis of Pomphorhynchus laevis. (bar $=25 \mu \mathrm{m})$

class. The mean intensity and the range of intensity for each length class are shown in Table 1.

The values of Fulton's condition factor $(K)$ for the fish host ranged from 0.84 to 1.66 (average 1.22). Statistically significant differences were found in condition factors between fish size classes (one-way ANOVA) $(F=3.101 ; p=0.002)$. The condition factor from each size group was computed to analyze the influence of $P$. laevis on fish condition; no significant differences were found (Kruskal Wallis $H$ test $p>0.05$ ). Even though the mean abundance of $P$. laevis increased with increasing fish size, the mean condition factor also increased. There was no statistically significant difference in spatial distribution of $P$. laevis among the different parts of the digestive tract was observed (Kruskal-Wallis $H$ test $p>0.05$ ), but the parasite tended to prefer (47.9\%) the pyloric caeca. 


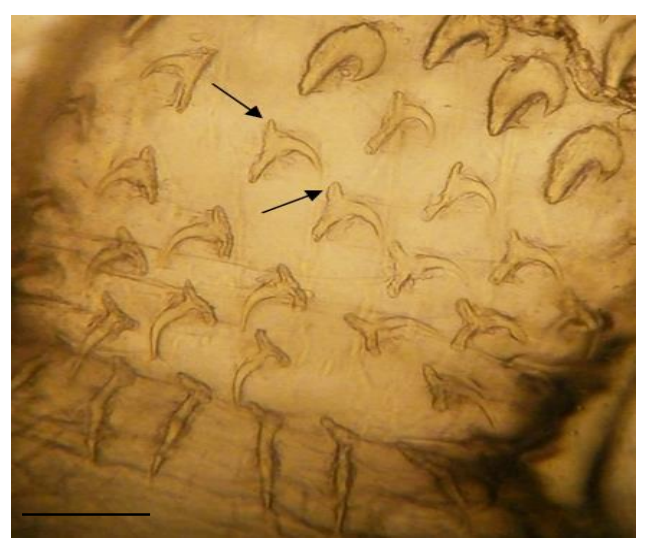

Figure 5. Hooks on the posterior half of the proboscis of Pomphorhynchus laevis have proximal projections on the base (arrows) from unfixed fresh material (bar $=25 \mu \mathrm{m})$

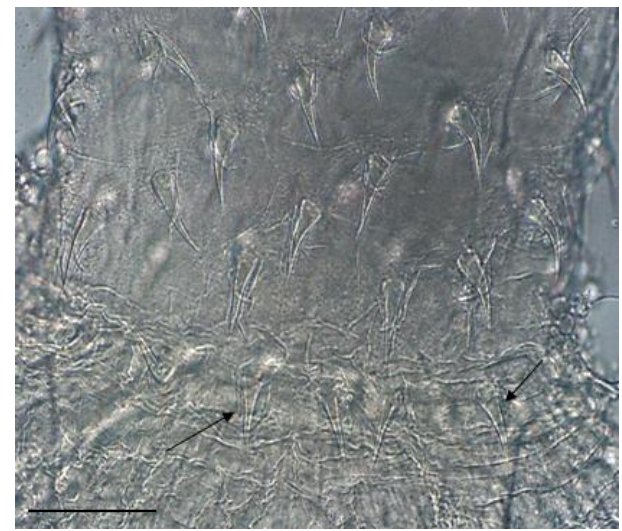

Figure 6. The last hook row (arrows) stands at the posterior-most end of the proboscis of Pomphorhynchus laevis (bar $=50 \mu \mathrm{m}$ )
The spatial distribution and infection parameters of the $P$. laevis within the digestive tract are shown in Table 2. Gammarus obnixus was observed as intermediate host of $P$. laevis in the net cage area. $P$. laevis cystacanths infected 119 $(19.3 \%$ ) of the 617 G. obnixus specimens (Fig. 7) examined in November. The mean intensity and mean abundance of cystacanths was found to be 2.05 and 0.36 respectively. Intensities of infection ranged from one to nine cystacanths per G. obnixus.

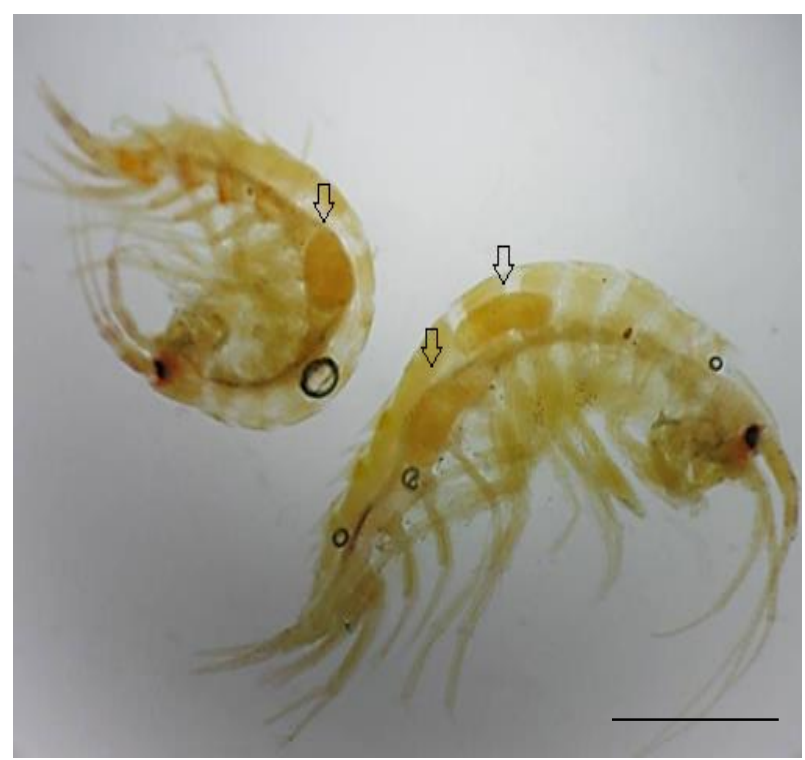

Figure 7. Pomphorhynchus laevis cystacanths (arrows) in the haemocoel of Gammarus obnixus from lşıkı Spring (bar = $2 \mathrm{~mm}$ )

Table 1. Size classes of cage-reared Oncorhynchus mykiss and parameters of infection by Pomphorhynchus laevis in Işıklı Spring

\begin{tabular}{lcccccc}
\hline $\begin{array}{l}\text { Length } \\
\text { (cm) }\end{array}$ & $\begin{array}{c}\text { Number of } \\
\text { fish } \\
\text { examined }\end{array}$ & $\begin{array}{c}\text { Infected fish } \\
\text { number }\end{array}$ & $\begin{array}{c}\text { Total number } \\
\text { of parasites }\end{array}$ & $\begin{array}{c}\text { Mean } \\
\text { abundance }\end{array}$ & Mean intensity & $\begin{array}{c}\text { Parasite } \\
\text { intensity } \\
\text { min - max }\end{array}$ \\
\hline $5.0-6.9$ & 6 & 2 & 3 & 0.5 & 1.5 & $1-2$ \\
$7.0-8.9$ & 15 & 12 & 51 & 3.4 & 4.25 & $1-8$ \\
$9.0-10.9$ & 28 & 19 & 42 & 1.5 & 2.21 & $1-5$ \\
$11.0-12.9$ & 27 & 22 & 104 & 3.9 & 4.72 & $1-20$ \\
$13.0-14.9$ & 55 & 43 & 230 & 4.2 & 5.34 & $1-17$ \\
$15.0-16.9$ & 31 & 22 & 145 & 4.6 & 6.59 & $1-18$ \\
$17.0-18.9$ & 19 & 14 & 91 & 4.7 & 6.5 & $1-31$ \\
$19.0-20.9$ & 12 & 11 & 160 & 13.3 & 14.5 & $4-34$ \\
$21.0-22.9$ & 11 & 11 & 98 & 8.9 & 8.9 & $1-17$ \\
$23.0-24.9$ & 12 & 11 & 144 & 12.0 & 13.09 & $2-45$ \\
$25.0-26.9$ & 5 & 5 & 92 & 18.4 & 18.4 & $2-63$ \\
\hline
\end{tabular}


Table 2. Spatial distribution and infection parameters of Pomphorhynchus laevis within the digestive tract of Oncorhynchus mykiss in Işıklı Spring

\begin{tabular}{lccccc}
\hline Location of parasite & $\begin{array}{c}\text { Total parasite } \\
\text { number }\end{array}$ & $\begin{array}{c}\text { Prevalence } \\
(\%)\end{array}$ & Mean intensity & $\begin{array}{c}\text { Mean } \\
\text { abundance }\end{array}$ & $\begin{array}{c}\text { Parasite } \\
\text { intensity } \\
\text { min-max }\end{array}$ \\
\hline Pyloric stomach & 60 & 5.2 & 3.2 & 0.3 & $1-18$ \\
Pyloric caeca & 556 & 47.9 & 4.3 & 2.5 & $1-24$ \\
Anterior intestine & 143 & 12.3 & 3.2 & 0.6 & $1-18$ \\
Mid intestine & 207 & 17.8 & 2.7 & 0.9 & $1-11$ \\
Posterior intestine & 191 & 16.5 & 2.6 & 0.9 & $1-17$ \\
\hline
\end{tabular}

\section{DISCUSSION}

Turkey is the largest producer of farmed trout in Europe with an annual production of 85,250 tons. 78,150 tons come from inland aquaculture with the remaining 7,100 tons from seawater production (Bozoğlu et al., 2007). Oncorhynchus mykiss is the main freshwater fish species cultured in Turkey and cage farming of rainbow trout has become widespread in lakes and reservoirs during the last few decades. However, few studies have reported on parasites of trout in Turkey. Soylu, (1996) recorded Ichthyobodo necator (Henneguy, 1883), Trichodina sp., Chilodonella cyprini (Moroff, 1902) and Ichthyophthirius multifilis Fouquet, 1876 on farmed rainbow trout from the Marmara region. Altunay and Yıldız (2008) found Trichodina sp., Epistylis sp., Chilodonella sp., Costia sp., Apiosoma sp. and Tripartella sp. on cage-cultured O. mykiss from Kesikköprü Dam Lake. Özer et al. (2010) recorded $I$. multifiliis, Trichodina sp. and Chilodonella sp. and Öğüt and Parlak (2014) recorded Hexamita salmonis in the same fish host. At least 23 protozoan and 169 metazoan parasites are known to occur in rainbow trout throughout the world (Lom and Dykova, 1992; Buchmann et al., 1995). Protozoan parasites represent one of the most important groups of pathogens that negatively affect the health of cultured and feral fish (Scholz, 1999). Outside of the cage-rearing system, when Oncorhynchus mykiss are maintained in concrete ponds, artificially fed and treated with therapeutic products, cleaning and sterilizing ponds are the effective ways of reducing the numbers of the intermediate hosts of some parasites. When fish are fed with processed food under farmed conditions, transmission of many indirectly transmitted parasites is blocked (Johansen et al., 2011). In the present study the parasite infracommunity of the fish host was dominated by a single species, Pomphorhynchus laevis. Morphological analysis of proboscis hooks of the specimens are very similar to $P$. tereticollis, but there are several differences. The last row of hooks is not situated in bulbus, and hooks shorter. As a result, the morphology is slightly different from $P$. tereticollis and it is different apparently also from $P$. laevis (M. Spakulova, personal communication). Phylogeography of $P$. laevis and $P$. tereticollis appear rather complex especially for $P$. laevis with rather old lineages in the peri-Mediterranean area genetically more distant to $P$. tereticollis. There is a rather large genetic differentiation within $P$. laevis at pan-European scale, Mediterranean lineages seem to be older and more differentiated. Phylogeographic analysis shows that this lineages of Pomphorhynchus bracnhes is between Pomphorhynchus from Italy (oldest lineages) and those other parts of Europa (Danube-Volga lineages and west Europe lineages). If mentioning these clusters, Italian and Turkey and may be Danubian are quite distant (J-M. Perrot-Minnot, personal communication). Cages constitute an open system, which allows free exchange between wild and caged organisms, leading to the exposure to disease-causing agents (Merella et al., 2006). Some parasite species with complex life cycles cause phenotypic changes in their intermediate hosts that appear to enhance trophic transmission to their final hosts (Cezilly et al., 2014). Infected hosts often show alterations in behaviour in addition to changes in their appearance (Kaldonski et al., 2009). For example, the orange colouring of the $P$. laevis cystacanths coincides with the changed behaviour of the intermediate host (gammarids) that swims near the surface of the water, maximising their chances of transmission to the next host (Theo et al., 1997). Gammarus obnixus infected with cystacanths of $P$. laevis were found on the leaves of densely populated aquatic plants around the net cages. The mean intensity of $P$. laevis in our study increased along with the size classes of $O$. mykiss. This is an usual process because larger fish accumulate more parasites and can feed on larger amphipods that harboured high number and larger cysthacanths than small amphipods. Dezfuli et al. (2002) found $P$. laevis in the posterior part of trout middle intestine.

The preferred attachment site of $P$. laevis in our study was the pyloric caeca of the fish alimentary tract. Trichodina sp., Ichthyophthirius multifiliis and Diplostomum sp. were found scarcely, probably due to therapeutic chemical treatments. Use of formalin and Chloramine-T have been observed in control of ectoparasites in this trout farm during study period. According to the results, there was no appreciable effect of $P$. laevis on the condition factor of the fish host. 


\section{ACKNOWLEDGEMENTS}

This article was extracted from a Master's thesis conducted at the Institute for Graduate Studies in Pure and Applied Sciences, Marmara University. The authors would like to thank Dr. M.J. Perrot-Minnot for molecular analyses of the parasite.
We would like to thank Dr. M Špakulová for her valuable comments on the manuscript.

We would like to thank Işıklı Village Agricultural Irrigation Association for providing the research facility.

\section{REFERENCES}

Altunay, S., \& Yıldız, H.J. (2008). Ectoparasitological examination of rainbow trout (Onchorhynchus mykiss Walbaum, 1792) cage cultured in Kesikköprü Dam Lake. Ankara University Faculty of Agriculture Journal of Agricultural Science, 14: 154-162.

Aygen, C., \& Balık, S. (2005). Işıklı Gölü ve Kaynaklarının (Çivril-Denizli) Crustacea Faunası Üzerine Araştırmalar. Ege University Journal of Fisheries Aquatic Science, 22(3-4): 371-375.

Bombarová, M., Marec, F., Nguyen, P., \& Špakulová, M. (2007). Divergent location of ribosomal genes in chromosomes of fish thorny-headed worms, Pomphorhynchus laevis and Pomphorhynchus tereticollis (Acanthocephala). Genetica, 131: 141-149. doi: 10.1007/s10709-006-9124-3

Bozoğlu, M., Ceyhan, V., Cinemre, H.A., Demiryürek, K., \& Kılıç, O. (2007) Important factors affecting trout production in the Black Sea Region, Turkey. Czech Journal of Animal Science, 52: 308-313.

Buchmann, K., Uldal, A., \& Lyholt, H. (1995). A checklist of metazoan parasites from rainbow trout (Onchorhynchus mykiss Walbaum, 1792). Acta Veterinaria Scandinavica, 36: 299-318.

Bullock, W.L. (1963). Intestinal histology of some salmonid fishes with particular reference to the histopathology of acanthocephalan infections. Journal of Morphology, 112: 23-44. doi: 10.1002/jmor.1051120104

Bush, A.O., Lafferty, K.D., Lotz, J.M., \& Shostak, A.W. (1997). Parasitology meets ecology on its own terms: Margolis et al. revisited. Journal of Parasitology, 83: 575-583. doi: 10.2307/3284227

Bykhovskaya-Pavlovskaya, I.E., Gussev, A.V., Dubinina, M.N., Izyumova N.A., Simirnova, T.S., Sokolovskaya, I., Shtein, G.A., Shulman, S., \& Epshtein, V.M. (1962). Key to parasites of freshwater fish of the USSR. Izdatelsvi Akademi Nauk SSSR. Moskva Leningrad: 919 pp.

Cezilly, F., Perrot-Minnot, M.J., \& Rigaud, T. (2014). Cooperation and conflict in host manipulation: interactions among macro-parasites and microorganisms. Frontiers in Microbiology, 5: 144-153.

Dezfuli, B.S., Castaldelli, G., Bo, T., Lorenzoni, M., \& Giari, L. (2011). Intestinal immune response of Silurus glanis and Barbus barbus naturally infected with Pomphorhynchus laevis (Acanthocephala). Parasite Immunology, 33 116-123. doi: 10.1111/j.1365-3024.2010.01266.x

Dezfuli, B.S., Simoni, E., Duclos, L. \& Rossetti, E. (2008). Crustacean acanthocephalan interaction and host cell-mediated immunity: parasite encapsulation and melanization. Folia Parasitologica, 55: 9-53. doi: 10.14411/fp.2008.007

Dezfuli, B.S., Pirioni, F., Giari, L., Domeneghini, C. \& Bosi, G. (2002). Effect of Pomphorhynchus laevis (Acanthocephala) on putative neuromodulators in the intestine of naturally infected Salmo trutta. Diseases of Aquatic Organisms, 51: 27-35. doi: 10.3354/dao051027

Dezfuli, B.S., Rossette, E., Bellettato, C.M., \& Maynard, B.J. (1999) Pomphorhynchus laevis in its intermediate host Echinogammarus stammeri in the river Brenta, Italy. Journal of Helminthology, 73: 95-102.

Düsen, S., \& Oğuz, M.C. (2008). Occurrence of Pomphorhynchus laevis (Acanthocephala) in the marsh frog (Rana ridibunda Pallas, 1771), from Turkey. Helminthologia, 45: 154-156. doi: 10.2478/s11687-008-0031-2

Heckmann, R.A., Oguz, M.C., Amin, O.M., Dusen, S., Tepe, Y. \& Aslan, B. (2010). Host and geographical distribution of Pomphorhynchus spindletrancatus (Acanthocephala: Pomphorhynchidae) in Turkey, with enhanced description from new fish and amphibian hosts using SEM, and histopathological notes. Scientia Parasitologica , 11: 129-139.
Johansen, L.H., Jense, I., Mikkelsen, H., Bjorn, P.A., Jansen, P.A., \& Bergh, O. (2011). Disease interaction and pathogens exchange between wild and farmed fish populations with special reference to Norway. Aquaculture, 315: 167-186. doi: 10.1016/j.aquaculture.2011.02.014

Kaldonski, N., Perrot-Minnot, M.J., Dodet, R., Martinaud, G., \& Cezilly, F (2009). Carotenoid-based colour of acanthocephalan cystacanths plays no role in host manipulation. Proceedings of the Royal Society B-Biological Sciences, 276: 169-176. doi: 10.1098/rspb.2008.0798

Kirin, D., Hanzelová, V., Shukerova, S., \& Kuzmanova, D. (2014). Biodiversity, bioindication and helminth communities of Abramis brama (Linnaeus, 1758) from the Danube River and Lake Srebarna, Bulgaria. Turkish Journal of Agricultural and Natural Sciences, Special Issue 1: 727-733.

Lom, J., \& Dykova, I. (1992). Protozoan parasites of fishes. Series: Developments in Aquaculture and Fisheries Science. Elsevier, Amsterdam, $315 \mathrm{pp}$.

Merella, P., Garippa, G., \& Salati, F. (2006). Parasites of cage cultured European sea bass Dicentrarchus labrax and gilthead sea bream Sparus aurata from Sardinia (western Mediterranean): first results. Parassitologia, 48: $1-2$.

Niewiadomska, K. (2003). The parasites of Polish fish (key to species identification). The flukes-Digenea. Warszawa: P.T.P.169 pp.

Ögüt, H., \& Parlak, R. (2014). Hexamitiasis leads to lower metabolic rates in rainbow trout (Onchorhynchus mykiss Walbaum, 1792) juveniles. Journal of Fish Diseases, 37: 1013-1020. doi: 10.1111/jfd.12188

Özer, S., Koyuncu, E., Dönmez, E., \& Bulduklu, P.S. (2010). Protozoan ectoparasites of rainbow trout (Onchorhynchus mykiss Walbaum, 1792) cultivated in Mersin. Journal of Pendik Veterinary Microbiology, 37: 43-52.

Perrot-Minnot, M.J. (2004). Larval morphology, genetic divergence, and contrasting levels of host manipulation between forms of Pomphorhynchus laevis (Acanthocephala). International Journal for Parasitology, 34: 45-54. doi: 10.1016/j.jpara.2003.10.005

Scholz, T. (1999). Parasites in cultured and feral fish. Veterinary Parasitology, 84: 317-335. doi: 10.1016/S0304-4017(99)00039-4

Smales, L.R., Aydogdu, A., \& Emre, Y. (2012). Pomphorhynchidae and quadrigyridae (Acanthocephala), including a new genus and species (Pallisentinae), from freshwater fishes, Cobitidae and Cyprinodontidae, in Turkey. Folia Parasitologica, 59: 162-166. doi: 10.14411/fp.2012.022

Soylu, E. (1996). Protozoan ectoparasites of Oncorhynchus mykiss recorded from farms in Marmara Region, Turkey. Anadolu University Journal of Science and Technology, 1: 19-26.

Špakulová, M., Perrot-Minnot, M.J., \& Neuhaus, B. (2011). Resurrection of Pomphorhynchus tereticollis (Rudolphi, 1809) (Acanthocephala: Pomphorhynchidae) based on new morphological and molecular data. Helminthologia, 48: 268-277. doi: 10.2478/s11687-011-0038-y

Taraschewski, H. (2000). Host-parasite interactions in Acanthocephala: a morphological approach. Advances in Parasitology, 46: 1-179. doi: 10.1016/S0065-308X(00)46008-2

Theo, C., Bakker, M., Mazzi, D., \& Zala, S. (1997). Parasite-induced changes in behavior and color make Gammarus pulex more prone to fish predation. Ecology, 78: 1098-1104. doi: 10.2307/2265861

Yıldı, K., \& Cavusoglu, K.A. (2003). Scanning electron microscope examination of Pomphorhynchus laevis. Turkish Journal of Veterinary and Animal Sciences, 27: 1357-1360. 